\title{
Detection of potential pathogenic aerobic bacteria from egg shell and egg contents of hen collected from poultry
}

\author{
Fardows $\mathbf{J}^{1}$, Shamsuzzaman $\mathrm{SM}^{2}$ \\ ${ }^{1}$ Department of Microbiology, Dhaka Medical College, Dhaka, Bangladesh. ${ }^{2}$ Department of Microbiology, \\ Dhaka Medical College, Dhaka, Bangladesh. \\ Email:smszaman@yahoo.com
}

\begin{abstract}
This study was done to identify different pathogenic aerobic bacteria from egg shell and egg contents of hen. Egg shells and egg contents of 150 eggs collected from poultry were tested. Of 150 egg shells, 130 (86.67\%) yielded growth of bacteria and 60 (40\%) Esch. coli, 25 (16.67\%) Providencia rettgeri, 5 (3.33\%) Providencia alkalifaciens, 20 (13.33\%) Citrobacter freundii, 10 (6.67\%) Salmonella spp, $10(6.67 \%)$ Enterobacter aerogenes were isolated. No bacteria were isolated from 150 egg contents. Total 14 (9.33\%) Salmonella spp. from egg shells and 7 (4.67\%) Salmonella spp. from egg contents were identified by PCR. Most of the identified serotypes were Salmonella Enteritidis (42.86\% from egg shells and $71.43 \%$ from egg contents). All (100\%) Salmonella Typhi and Salmonella Paratyphi A were sensitive to ciprofloxacin and ceftriaxone.
\end{abstract}

Key words: aerobic bacteria, Salmonella, poultry eggs, culture, PCR.

\section{Introduction}

Poultry products especially eggs and egg products are nutritive food items and a vital constituent of human food in the world. ${ }^{1}$ Inaccurately treated eggs can cause food-borne illness and it is a major public health problem and the main cause of diarrheal diseases affecting all developed and developing countries. ${ }^{2}$ The absence of standard structures and drainage system in the poultry and relatively high humidity could have contributed to the high microbial growth. ${ }^{3}$ Eggs have natural defense system against the contaminating microbes, such as cuticle, calcium hard shell, shell membrane and some antibacterial factors. ${ }^{4}$ In spite of these, it can be contaminated with different food borne pathogen such as Salmonella spp., Esch coli, Listeria monocytogens, Campylobacter jejuni, Proteus spp. and Klebsiella spp. ${ }^{3}$ It can be contaminated during formation and laying process. ${ }^{5}$ Eggs have more possibility to become infected than fresh eggs due to the degradation of natural defense mechanisms in egg. Bacterial contamination can happen at three main parts of egg (egg yolk, albumen and shell membrane / egg shell). ${ }^{6}$ Salmonella Enteritidis is able to invade the cells of the follicles before ovulation. ${ }^{7}$
It is estimated that in the U.S. Salmonella transmission through contaminated egg shell or egg products results in 48 million cases of salmonellosis and costs \$365 million annually. ${ }^{8}$ Other than enteric fever, the majority of infections results in asymptomatic or self-limited disease; however, in immuno-compromised patients, neonates and elderly, it requires antibiotic treatment. ${ }^{9}$ The use of antibiotics in animals disrupts normal flora of intestine, resulting in to emergence of antibiotic-resistant Salmonella and their prolonged fecal shedding into the environment. Recently multi-drug resistant (MDR) strains have emerged, presumably due to the extensive use of antibiotic in veterinary practice. $^{10}$

Salmonella isolation by conventional culture methods are based on pre-enrichment, enrichment and plating on selective and differential media and suspected colonies are then confirmed by biochemical and serological methods. ${ }^{9,11}$ Generally these techniques take longer time and they give only presumptive results. ${ }^{9} \mathrm{PCR}$ for gene amplification has made it possible to detect low numbers of infectious agents. ${ }^{12}$ One study has been done in Bangladesh regarding Salmonella 
isolation by culture in $2011^{9}$ and one study has been done regarding Salmonella identification by PCR in $2012^{11}$ but only Salmonella Typhimurium has been identified. No study yet has been carried out regarding identification of other serotypes of Salmonella in Bangladesh. The specific objectives of this study are detection of different Salmonella serotypes from egg shells and egg contents of hen by culture and multiplex PCR and to see their antimicrobial susceptibility pattern.

\section{Materials and Methods}

This cross sectional study was done in the department of Microbiology, Dhaka Medical College (DMC), Dhaka, Bangladesh from July, 2012 to June, 2013. This protocol was approved by the Research Review Committee of the department of Microbiology of DMC and ethical clearance was obtained from the Ethical Review Committee of DMC. Oral consent was taken from poultry farm handlers before collecting eggs.

A total 150 poultry eggs were collected and both egg shells and egg contents were tested. Clean, undamaged eggs were included and focally contaminated and cracked eggs were excluded from this study. Eggs were collected directly from poultry farms in sterile containers and transported to the Microbiology laboratory of Dhaka Medical College with minimum delay.

Egg shell and egg contents processing, isolation and identification of organisms, serotyping of Salmonella, ESBL detection and antimicrobial sensitivity testing were done according to standard protocol.

Polymerase chain reaction (PCR): PCR was done conventionally and primers used for different serotype of Salmonella are listed in Table I.

\section{Result}

Among the 150 shells of eggs collected from poultry, $130(86.67 \%)$ yielded growth of different bacteria and none of the 150 egg contents yielded growth. Among the aerobic bacteria isolated from egg shells, Esch. coli was the most common organism (40\%) and $10(6.67 \%)$ were Salmonella spp. (Table II).
Total $14(9.33 \%)$ of the 150 egg shells and 7 (4.67\%) of the $150 \mathrm{egg}$ contents were positive for Salmonella by PCR. Salmonella Enteritidis was the most common Salmonella serotype detected from egg shells and egg contents by PCR (Table III and Fig 1).

Table I: Serotypes of Salmonella with their genes, primers and their amplified product used in the study:

\begin{tabular}{|c|c|c|c|c|}
\hline Name & Genes & primers & Sequence $\left(5^{\prime}-3{ }^{\prime}\right)$ & $\begin{array}{l}\text { Base } \\
\text { pair }\end{array}$ \\
\hline $\begin{array}{l}\text { Salmonella } \\
\text { spp. }\end{array}$ & $i n v A^{13}$ & $\begin{array}{l}\text { fliC-s } \\
\text { fliC-as }\end{array}$ & $\begin{array}{l}\text { F-ATAGCCATCTTTACCAGTTCCCCC } \\
\text { R-GCTGCAACTGTTACAGGAATATGCC }\end{array}$ & $284 \mathrm{bp}$ \\
\hline $\begin{array}{l}\text { Salmonella } \\
\text { Typhimuriu } \\
\mathrm{m}\end{array}$ & $f l i C^{13}$ & $\begin{array}{l}\text { fliC-s } \\
\text { fliC-as }\end{array}$ & $\begin{array}{l}\text { F- ATAGCCATCTTTACCAGTTCCCCC } \\
\text { R- GCTGCAACTGTTACAGGAATATGCC }\end{array}$ & $183 \mathrm{bp}$ \\
\hline $\begin{array}{l}\text { Salmonella } \\
\text { Enteritidis }\end{array}$ & $\operatorname{sef} A^{14}$ & $\begin{array}{l}\text { SEFA2 } \\
\text { SEFA4 }\end{array}$ & $\begin{array}{l}\text { F-GCAGCGGTTACTATTGCAGC } \\
\text { R-TGTACAGGGACATTTAGCG }\end{array}$ & $310 \mathrm{bp}$ \\
\hline $\begin{array}{l}\text { Salmonella } \\
\text { Typhi } \\
\text { (O antigen) }\end{array}$ & $T y v^{15}$ & $\begin{array}{l}\text { tyv-s } \\
\text { tyv-as }\end{array}$ & $\begin{array}{l}\text { F-GAGGAAGGGAAATGAAGCTTTT } \\
\text { R- TAGCAAACTGTCTCCCACCATAC }\end{array}$ & $615 \mathrm{bp}$ \\
\hline $\begin{array}{l}\text { Salmonella } \\
\text { Paratyphi A } \\
\text { (O antigen) }\end{array}$ & $\operatorname{Prt}^{15}$ & $\begin{array}{l}\text { parat-s } \\
\text { parat-as }\end{array}$ & $\begin{array}{l}\text { F-CTTGCTATGGAAGACATAACGAAC } \\
\text { R-CGTCTCCATCAAAAGCTCCATAGA }\end{array}$ & $258 \mathrm{bp}$ \\
\hline $\begin{array}{l}\text { Salmonella } \\
\text { Typhi }(\mathrm{H} \\
\text { antigen) }\end{array}$ & $\mathrm{fliC}^{15}$ & $\begin{array}{l}\text { fliCcom-s } \\
\text { fliCd-as }\end{array}$ & $\begin{array}{l}\text { F-AATCAACAACAACCTGCAGCG } \\
\text { R-GCATAGCCACCATCAATAACC }\end{array}$ & $750 \mathrm{bp}$ \\
\hline $\begin{array}{l}\text { Salmonella } \\
\text { Paratyphi A } \\
\text { (H antigen) }\end{array}$ & $f l i C^{15}$ & $\begin{array}{l}\text { fliCcom-s } \\
\text { fliCa-as }\end{array}$ & $\begin{array}{l}\text { F-AATCAACAACAACCTGCAGCG } \\
\text { R-TAGTGCTTAATGTAGCCGAAGG }\end{array}$ & $329 \mathrm{bp}$ \\
\hline
\end{tabular}

Table II: Frequencies of microbial isolates from egg shells among poultry eggs $(n=150)$.

\begin{tabular}{ll}
\hline \multicolumn{1}{c}{ Types of isolates } & \multicolumn{1}{c}{$\mathrm{n}(\%)$} \\
\hline Esch. coli & $60(40.00)$ \\
Providencia rettgeri & $25(16.67)$ \\
Providencia alkalifaciens & $5(3.33)$ \\
Citrobacter freundii & $20(13.33)$ \\
Enterobacter aerogenes & $10(6.67)$ \\
Salmonella Typhi & $1(0.67)$ \\
Salmonella Paratyphi A & $1(0.67)$ \\
Others serotypes of Salmonella & $8(5.33)$ \\
\hline Total & $130(86.67)$ \\
\hline
\end{tabular}

Of the 150 egg shells, 8 (80\%) were positive by both culture and PCR. Six (4.29\%) were positive by PCR but negative by culture and $2(20 \%)$ was negative by PCR but positive by culture (TableIV). Considering culture as gold standard, the sensitivity of PCR was $80 \%$, specificity was $95.71 \%$, positive predictive value was $57.14 \%$, negative predictive value was $98.53 \%$ and accuracy was $94.67 \%$. The difference in positivity between culture and PCR was statistically significant $(\mathrm{p}<0.001)$. 


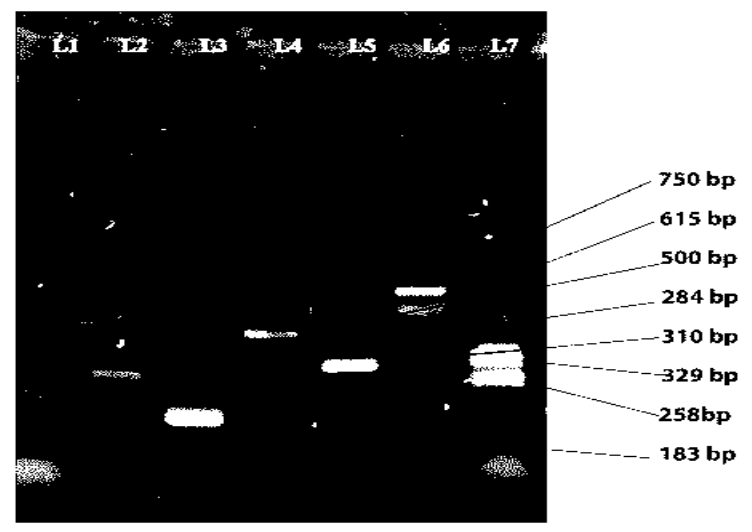

Fig. 1: Photograph of amplified DNA of different serotypes of Salmonella. Negative control Esch. coli ATCC 25922 (lane 1). Amplified DNA of $284 \mathrm{bp}$ for invA gene of Salmonella spp. (lane 2), $183 \mathrm{bp}$ for $f l i C$ gene of $S$. Typhimurium (lane 3), $310 \mathrm{bp}$ for sefA gene of $S$. Enteritidis (lane 5), $750 \mathrm{bp}$ and $615 \mathrm{bp}$ for fliC and tyv gene of $S$. Typhi (lane 6) and $329 \mathrm{bp}$ and $258 \mathrm{bp}$ for $f l i C$ and prt gene of $S$. Paratyphi A (lane 7). Hundred base pair DNA (lane $4)$.

In the antimicrobial resistance pattern of Salmonella, no serotype was resistant to chloramphenicol, imipenem and gentamicin. The $2(50 \%)$ isolated Salmonella Typhimurium were resistant to nalidixic acid and one $(25 \%)$ to ciprofloxacin and ceftriaxone. All the isolated Salmonella Typhi and Salmonella Paratyphi A were sensitive to most of the antibiotics (Table$\mathrm{V})$.

\section{Discussion}

In this study, among the eggs collected from poultry farms, $86.67 \%$ egg shells and no egg contents yielded growth of pathogenic bacteria. In Iran $68.28 \%$ egg shells and in Thailand, $96.3 \%$ eggs collected from poultry yielded growth of pathogenic bacteria. ${ }^{2,16}$ These bacterial contaminations might be from cloths and hands of poultry workers, use of same tray, environment, weather condition of the poultry. ${ }^{3}$ In the developing countries specially Bangladesh, there are many poultry farms and inadequate refrigeration even no refrigeration, improper handling can increase the percentage of different bacterial contamination on egg shell.

Among the total isolated aerobic bacteria, 40\% were Esch. coli (Table II). In India, relatively lower percentage of aerobic bacteria $(28.74 \%)$ was observed ${ }^{17}$ and in Iran, only $9 \%$ Esch. coli was reported. ${ }^{5}$ Though Esch. coli is a normal inhabitant of intestinal tract of birds and it is of low risk for people but chickens are susceptible to colonization with Esch. coli O157:H7, an important Shiga toxin-producing, enterohemorrhagic pathogen for human. ${ }^{5}$ In addition, other diarrhoeagenic Esch. coli like enterotoxigenic Esch. coli (ETEC), enteropathogenic Esch. coli (EPEC), enteroinvasive Esch. Coli (EIEC), enteroaggregative Esch. coli (EagEC) and diffusely adherent Esch. coli may also contaminate egg shell from the farm handlers and environment. In this study, however, attempt to detect these diarrhoeagenic strains was not made. In addition to other gram negative bacteria, 10 (6.67\%) Salmonella spp. were isolated. Enteric fever is endemic in many developing countries particularly Indian subcontinent including Bangladesh. ${ }^{18}$ It is known to all that Salmonella transmission occurs mainly by food and drink. So, egg might be an important source of Salmonella transmission. Few studies in Bangladesh reported $8 \%$ - 12\% Salmonella from eggs, however, prevalence of different Salmonella serotype was not reported in those studies. ${ }^{9,11}$

Table III: Identification of different Salmonella serotypes by PCR among Salmonella DNA positive sample from egg shells $(n=14)$ and egg contents $(n=7)$

\begin{tabular}{lll}
\hline \multicolumn{1}{c}{$\begin{array}{c}\text { Salmonella } \\
\text { serotypes }\end{array}$} & \multicolumn{1}{c}{$\begin{array}{c}\text { Egg shells } \\
\text { Positive n (\%) }\end{array}$} & $\begin{array}{c}\text { Egg contents } \\
\text { Positive n (\%) }\end{array}$ \\
\hline S. Enteritidis & $6(42.86)$ & $5(71.43)$ \\
S. Typhimurium & $4(28.57)$ & - \\
S. Typhi & $1(7.14)$ & - \\
S. Paratyphi A & $1(7.14)$ & - \\
Unidentified & $2(14.29)$ & $2(28.57)$ \\
Salmonella & $14(100.00)$ & $7(100.00)$ \\
Total &
\end{tabular}

In the present study, 9.33\% egg shells were positive for Salmonella by PCR by genus specific primer; $42.86 \%$ of the PCR detected Salmonella Were Salmonella Enteritidis and $28.57 \%$ were Salmonella Typhimurium (Table III). In this study, Salmonella Typhi and Salmonella Paratyphi A were identified but in relatively lower percentage. In India, $29.09 \% \mathrm{~S}$. Enteritidis and $1.5 \% \mathrm{~S}$. Typhimurium was observed in egg shell. ${ }^{19,20}$ In this study, 7 (2.33\%) Salmonella were detected by PCR from egg contents and most were $S$. Enteritidis $(71.42 \%)$. Salmonella Enteritidis is the most frequently reported serovar from the egg shell as well as egg contents. ${ }^{21,22}$ In chicken it has been shown that both Salmonella Typhimurium and Salmonella Enteritidis infect the reproductive 
tract and contaminate eggs but Salmonella Enteritidis persists after eggs are laid.23 It has been proved that a specific gene possibly alters Salmonella Enteritidis interaction with egg albumin components, but Salmonella Typhimurium does not have this protective gene. ${ }^{24}$ In the present study, serotype could not be identified in 2 (14.29\%) Salmonella from egg shell and 2 (28.57\%) from egg contents by PCR.

Table IV: Comparison between results of culture and PCR for Salmonella spp.

\begin{tabular}{llll}
\hline \multicolumn{1}{c}{ PCR } & $\begin{array}{c}\text { Positive } \\
\mathrm{n}(\%)\end{array}$ & $\begin{array}{c}\text { Culture } \\
\text { Negative } \\
\mathrm{n}(\%)\end{array}$ & \multicolumn{1}{c}{$\begin{array}{c}\text { Total } \\
\mathrm{n}(\%)\end{array}$} \\
\hline Positive & $8(80.00)$ & $6(4.29)$ & $14(9.33)$ \\
Negative & $2(20.00)$ & $134(95.71)$ & $136(90.67)$ \\
Total & $10(100.00)$ & $140(100.00)$ & $150(100.00)$
\end{tabular}

$\chi^{2}=39.0, \mathrm{df}=1, \mathrm{p}<0.001$. The difference in positivity between culture and PCR was statistically significant.

These negative findings might be due to the fact that we did not use all primers of other Salmonella and these unidentified Salmonella might also be Salmonella Enteritidis or Salmonella Typhimurium but other phage type. ${ }^{25}$

Table V: Antimicrobial resistance pattern of different serotypes of Salmonella.

\begin{tabular}{lllll}
\hline \multicolumn{1}{c}{ Antibiotics } & $\begin{array}{c}\text { Enteriti } \\
\text { dis } \\
(\mathrm{n}=6)\end{array}$ & $\begin{array}{c}\text { S.Typhi } \\
\text { murium } \\
(\mathrm{n}=4)\end{array}$ & $\begin{array}{c}S . \\
\text { Typhi } \\
(\mathrm{n}=1)\end{array}$ & $\begin{array}{c}S . \\
\text { Paratyp } \\
\text { hi A } \\
(\mathrm{n}=1)\end{array}$ \\
\hline Chloramphenicol & $0(0.0)$ & $0(0.0)$ & $0(0.0)$ & $0(0.0)$ \\
Nalidixic acid & $5(83.3)$ & $2(50.0)$ & $0(0.0)$ & $0(0.0)$ \\
Imipenem & $0(0.0)$ & $0(0.0)$ & $0(0.0)$ & $0(0.0)$ \\
Amikacin & $3(50.0)$ & $2(50.0)$ & $1(100)$ & $1(100)$ \\
Ciprofloxacin & $0(0.0)$ & $1(25.0)$ & $0(0.0)$ & $0(0.0)$ \\
Gentamicin & $0(0.0)$ & $0(0.0)$ & $0(0.0)$ & $0(0.0)$ \\
Ceftriaxone & $0(0.0)$ & $1(25.0)$ & $0(0.0)$ & $0(0.0)$ \\
Azithromycin & $2(33.3)$ & $1(25.0)$ & $0(0.0)$ & $0(0.0)$ \\
Amoxycillin + & $5(83.3)$ & $2(50.0)$ & $0(0.0)$ & $0(0.0)$ \\
Clavulanic acid) & & & & \\
\hline
\end{tabular}

In this study, of the 14 Salmonella detected by PCR (Table IV), 10 were positive by culture $(p<0.001)$ and the sensitivity and specificity of PCR were similar to other study. ${ }^{26}$
Two Salmonella strains isolated by culture were negative in PCR even after repeated attempts of DNA extraction from the stored specimen and annealing. The reason of such negative PCR result in isolated Salmonella might be due to the fact that invA gene was detected in PCR in this study to detect Salmonella and these culture positive Salmonella strains might have invB or himA gene and PCR could not detect these genes. ${ }^{26}$ The higher sensitivity of PCR than culture is due to culture needs live bacteria but PCR can detect DNA of both live and dead bacteria and even presence of single DNA can be amplified and can be detected by PCR. ${ }^{13}$

In this study, all (100\%) Salmonella Typhi and Salmonella Paratyphi A were sensitive to ciprofloxacin, ceftriaxone and chloramphenicol (Table V). In human case, these are the effective drugs and widely used against Salmonella Typhi and Salmonella Paratyphi. ${ }^{27}$ But for the last few years' sensitivity of Salmonella to ciprofloxacin has been decreased and so far no ceftriaxone resistant Salmonella Typhi and Salmonella Paratyphi has been reported from human infection in Bangladesh. Multidrug resistant Salmonella Typhimurium was also reported from egg shell in Bangladesh. ${ }^{28}$ Although, no data was found that Salmonella Typhimurium is resistant to ceftriaxone but in the present study, one (25\%) Salmonella typhimurium were resistant to ceftriaxone which may give us cautionary signal regarding antibiotic resistance for Salmonella in future.

Conclusion: Eggs may be a source of transmission of different gram negative bacteria specially Salmonella and diarrhoeagenic Esch. coli from poultry to the community. Current study reflects that PCR is the sensitive method to detect Salmonella in culture negative samples. Present study also reflects that ceftriaxone, ciprofloxacin and chloramphenicol are the most effective drugs against Salmonella isolated from poultry eggs.

\section{Acknowledgement}

This work was done with laboratory support of department of Microbiology of Dhaka Medical College, Dhaka, Bangladesh. The authors thank the staffs of the poultry farms for providing necessary support during collection of eggs. 


\section{References}

1. Stepien-pysniak D. Occurrence of Gram-negative bacteria in hens' eggs depending on their source and storage conditions. Polish J Vet Sci 2010; 13 (3): 50713.

2. Akbar A, Anal AK. Food safety concerns and foodborne pathogens, Salmonella, Escherichia coli and Campylobacter. FUUAST J Biol 2011; (1): 5-17.

3. Safaei G, Jalali M, Hosseini A, Narimani T, Sharifzadeh A, Raheim E. The prevalence of bacterial contamination of table eggs from retails markets by Salmonella spp., Listeria monocytogenes, Campylobacter jejuni and Esch. coli in Shhrekord, Iran. Jundishapur J Microbiol 2011; 4 (4): 249- 53.

4. Akbar A, Anal KA. Zinc oxide nanoparticles loaded active packaging, a challenge study against Salmonella Typhimurium and Staphylococcus aureus in ready- to-eat poultry meat. Food Control 2014; 38 : 88-95.

5. Abdullah IN. Isolation and identification of some bacterial isolates from table egg. Al-Anbar J Net Sci 2010; 3 (2): 1025- 31.

6. Bahrouz MA, Al-Jaff C. The risk of bacterial contamination in hen eggs of Sulaimani poultries. J Zankoy Sulaimani 2014; 8A (1): 63-71.

7. Howard ZR, Moore RW, Zabala-Diaz IB, Landers KL, Byrd JA, Kubena LF, Nisbet DJ, Birkhold SG, Ricke SC. Ovarian laying hen follicular maturation and in-vitro Salmonella internalization. Vet Microbiol 2005; 108: 95-100.

8. CDC (Center for Disease Control and Prevention). Salmonella in egg: An Unwelcome summer visitor. Atlanta: Center for Disease Control and Prevention, 2013. Available at: http://www.cdcinfo@cdc,gov. (Last accessed on November 25, 2014).

9. Ahmed MM, Rhaman MM, Mahbub KR, Wahiduzzaman M. Characterization of antibiotic resistant Salmonella spp. isolated from chicken eggs of Dhaka city. J Sci Res 2011; 3 (1): 191- 96.

10. Pan TM, Liang YH. Identification of Salmonella Enteritidis isolates by polymerase chain reaction and multiplex polymerase chain reaction. Microb Immunol Infec 2002; 35: 147- 51.

11. Ahmed MM, Hossain MS, Mahbub KR, Khaleque HN, Hossain Z, Fakruddin M, Chowdhury A, Hossain MN, Alam MZ. Performance analysis of multiplex PCR based detection of Salmonella spp. and Salmonella Typhimurium in chicken egg sample. J Sci Res 2012; 2 (1): 25-32.
12. Gillespie BE, Mathew AG, Draughon FA, Jayarao BM, Oliver SP. Detection of Salmonella enteric somatic groups $\mathrm{C} 1$ and E1 by PCR-enzyme-linked immune sorbent assay. J Food Prot 2003; 66: 236770.

13. Rahn K, De Grandis S, Clark R, Mcewen S. Amplification of an invA gene sequence of Salmonella Typhimurium by PCR as a specific method of detection of Salmonella. Mol Cell Probe 1992; 6: 271-79.

14. Madadi MS, Azari M, Yazdani A. Evaluation of different plating medias and PCR in the detecting of Salmonella Enteritidis from eggs laid by Experimentally infected hens. J Anim Poult Sci 2012; 1 (1): 13-23.

15. Hirosh $\mathrm{K}$, Itoh KI, Nakajima $\mathrm{H}$, Kurazono $\mathrm{T}$, Yhamaguchi M. Selective amplification of tyv $(r f b E)$, prt $(r f b S)$, viaB and $f l i C$ genes by multiplex PCR for identification of Salmonella enterica serovar Typhi and Paratyphi A. J Clin Microbiol 2002; 40 (2): 63336.

16. De Reu K, Grijspeerdt K, Heyndrickx M. Bacterial eggshell contamination in conventional cages, furnished cages and aviary housing systems for laying hens. Br Poult Sci 2005; 46: 149-55.

17. Rajmani RS, Verma SP. Microbial flora of eggs and egg contents from organized and unorganized poultry farms. Indian J Vet Res 2011; 20: 73-76.

18. Dewan AM, Corner R, Hashizume M, Ongee ET. Typhoid Fever and Its Association with Environmental Factors in the Dhaka Metropolitan Area of Bangladesh: A Spatial and Time-Series Approach. PLoS Negl Trop Dis 2013; 7(1): e1998.

19. Day JB, Basavanna U, Sharma SK. Development of a cell culture method to isolate and enrich Salmonella Enteritidis from shell eggs for subsequent detection by real-time PCR. Appl Environ Microbiol 2009; 4: 612-30.

20. Nagappa K, Shantanu T, Brajmadhuri, Saxena MK, Singh SP. Isolated of Salmonella Typhimurium from poultry eggs and meat of Tarai region of Uttaranchal. Indian J Biotech 2007; 123:407-9.

21. Shazad A, Mahmood MS, Hussain, I, Siddique F, Abbas RZ. Prevalence of Salmonella species in hen eggs and egg storng-trays collected from poultry farms and marketing outlets of Faisalabad, Pakistan. Pak J Agri Sci 2012; 49 (4): 565-68.

22. Pui CF, Wong WC, Chai LC, Tunung R, Ubong A, Cheah Y. Review article of Salmonella: a foodborne pathogen. Int food Res J 2011; 18: 465- 73. 
23. Jebelli JA, Staji H, Ghazvinan K, Salimi MR, Mahdavi A. Prevalence of Salmonella spp. in the quail egg interior contents. Iranian. J Vet Med 2012; 6 (3): 191-96.

24. Clavijo RI, Loui C, Anderson GL, Riley LW, Lu S. Identification of genes associated with survival of Salmonella enterica serovar Enteritidis in chicken egg albumen. Appl Environ Microbiol 2006; 72: 1055-64.

25. Almeida C, Cerqueira L, Azevedo NF, Vieira MJ. Detection of Salmonella enterica serovar Enteritidis using real time PCR, immunocapture assay, PNA FISH and standard culture methods in different types of food samples. Int J Food Microbiol 2013; 161:1622.
26. Jamshidi A, Bassami MR, Afshari-Nic S. Identification of Salmonella spp. and Salmonella Typhimurium by a multiplex PCR-based assay from poultry carcasses in Mashhad- Iran Int. J Vet Res 2009; 3 (1): 43-48.

27. Hasan B, Nahar SG, Akter L, Sale A. Antimicrobial sensitivity pattern of Salmonella Typhi isolated from blood culture in a referral hospital. Bangladesh J Med Microbiol 2011; 5 (1): 16-20.

28. Begum K, Reza TA, Haque M, Hossain A, Hassan FMK, Hasan N, Akter N, Ahmed A, Barua U. Isolation, identification and antibiotic resistance pattern of Salmonella spp. from chicken eggs, intestines and environmental sample. Bangladesh J Pharmacol 2010; 13 (1): 245-50. 